\title{
A new genus of micro-whipscorpions (Schizomida: Hubbardiidae) from western Cuba
}

\section{Новый род схизомид (Schizomida: Hubbardiidae) с западной Кубы}

\author{
Rolando Teruel \\ P. Теруэль
}

Centro Oriental de Ecosistemas y Biodiversidad (Bioeco), Museo de Historia Natural “Tomás Romay". José A. Saco \# 601, esquina a Barnada; Santiago de Cuba 90100. Cuba. E-mail: rteruel@bioeco.cu

KEY WORDS: schizomids, taxonomy, new genus, America, Caribbean.

КЛЮЧЕВЫЕ СЛОВА: схизомиды, таксономия, новый род, Америка, Карибский бассейн.

ABSTRACT: A new monotypic genus is herein described to accommodate the Western Cuban endemic schizomid Schizomus decui Dumitresco, 1977, currently placed in the "dumitrescoae" species-group of Rowlandius Reddell et Cokendolpher, 1995. The new genus is diagnosed from all other Hubbardiinae by a combination of several morphological characters of both sexes, including a very strong sexual dimorphism in setation of the propeltidium and tergites IIVII, male pedipalp armature and female spermathecal structure.

РЕЗЮМЕ: Описан новый монотипический род схизомид, включающий эндемичный для Западной Кубы вид Schizomus decui Dumitresco, 1977, ранее помещаемый в группу видов “dumitrescoae" рода Rowlandius Reddell et Cokendolpher, 1995. Новый род отличается от всех других представителей подсемейства Hubbardiinae комбинацией выдающихся морфологических признаков обоих полов, включая сильный половой диморфизм вооружения пропельтидия и тергитов II-VII, вооружение педипальпы самца и строение сперматек самки.

\section{Introduction}

As an outcome of the second Cubano-Romanian speleological expedition to Cuba in 1973, Dumitresco [1977] described a very conspicuous schizomid from a single cave in northwestern Matanzas Province, which she named Schizomus decui. Soon after, in Part I of their serial revision of the New World schizomids, Rowland \& Reddell [1979] erected the "dumitrescoae" species-group inside Schizomus Cook, 1899 to accommodate $S$. decui, together with other 11 species from six Antillean islands (Cuba, Jamaica, Hispaniola, Mona, Desecheo, and Martinique) and one from mainland Central America (southern Costa Rica). In the same paper, the first record of $S$. decui from the (then) La Habana Province was also given by Rowland \& Reddell [1979].
Very few literature references to this rare species appeared thereafter, mostly because its collections were both scarce and sporadic. Armas \& Alayón [1984] listed $S$. decui as cave-dwelling and wrongly suggested it as a probable junior synonym of Schizomus antilus Hilton, 1933, without realizing the latter had been accurately synonymized already by Rowland \& Reddell [1980] under Schizomus portoricensis Chamberlin, 1922.

Later, Armas [1989] described and depicted the pedipalps of the homomorphic male and presented a second, rudimentary drawing of the spermathecae [Armas, 1989: fig. 5b], which was much less detailed than the fine line art originally published by Dumitresco [1977: fig. 5b]. In the same paper, Armas [1989: 24] unfairly stated that "... the possibility that S. decui could be a synonym of $S$. portoricensis, suggested by Armas \& Alayón [1984: 9], must be discarded" (original text in Spanish, English translation added herein).

In their global revision of schizomids, Reddell \& Cokendolpher [1995] described the genus Rowlandius for the former "dumitrescoae" species-group of Schizomus (which by then had already doubled its initial membership to 25 species) and transferred $S$. decui accordingly. From then on, only a few references were made to this schizomid [Armas, 2001, 2004, 2013; Harvey, 2003; Teruel, 2003], including its first record for Mayabeque Province [Armas, 2002]. Finally, Giupponi et al. [2016] revised the "dumitrescoae" speciesgroup and updated its diagnosis, but unfortunately no specimens of $R$. decui were revised and the authors relied entirely upon previously published data, being unaware that some of these were incomplete and/or even erroneous (see below).

\section{Methods and Material}

Specimens were studied under a Zeiss Stemi 2000$\mathrm{C}$ stereomicroscope equipped with a line-scale eyepiece for mensuration and a Canon PowerShot A620 digital camera for photographs. Chelicerae and female spermathecae were carefully dissected from specimens 
immersed in $80 \%$ ethanol and mounted on microscope slides in a drop of concentrated lactic acid. The slides were then transferred to an Optech-B3 microscope equipped with a DCM-310 image-capture system and observed continuously until all structures of interest became sharply visible and then photographed; last, all dissected body parts were stored in a micro-vial together with the specimen of origin. Habitat photos were taken with a Nikon Coolpix S8100 digital camera.

For all photos made with both microscopes, a variable series of consecutive-plane shots was taken depending on the field depth (i.e., the bulkiest the structure, the largest number of photos needed) and afterwards, all images of the same structure were assembled into a single fully-focused image using the free software CombineZP. All digital images were processed with Adobe Photoshop CS5 only for basic bright/contrast optimization, removing artifacts from the background and resizing to assemble the plates.

Unless otherwise noted, all character descriptions and measurements given in the text refer to adults of both sexes. General nomenclature corresponds to Reddell \& Cokendolpher [1995] except for flagellum subdivision and setation [Monjaraz-Ruedas et al., 2016]. Measurements were taken after Teruel [2003]: adult size refers to total length and includes the flagellum, which in males includes the pedicel. In the male flagellum, the pedicel/bulb angle was determined after Teruel [2015]. Setation pattern of tergites II-VII is herein given as a formula, with the setal count of each segment separated by slashes, i.e., a 2/2/2/2/2/2 formula means that each of the six tergites has only two setae (the standard for Hubbardiinae).

Classification of adult males in heteromorphic and homomorphic forms follows Armas [1989], i.e., pedipalps either quite different from or similar to females, respectively. Very recently, Giupponi et al. [2016] further subdivided the former into " $\alpha$ and $\beta$ heteromorphic", but such modification, although obvious and generally correct, is not followed here because pedipalp elongation within the heteromorphic form actually varies in a wider range, with intermediate forms that do not match what was proposed by Giupponi et al. [2016]; see for example Teruel [2003: 46, 57, 61; tabs. I, VIVII].

All specimens are preserved in $80 \%$ ethanol, and abbreviations of repositories as follows: Institut de Spéologie "Emile Racovitza", Bucharest, Romania (ISER), Instituto de Ecología y Sistemática, Havana, Cuba (IES), present author's personal collection (RTO).

\section{Systematics}

\section{Dumitrescoella gen.n.}

Figs. 1-5.

Schizomus [in part: references to $S$. decui only]: Dumitresco, 1977: 147, 151-157; figs. 4-5; Rowland, Reddell, 1979: 161, 163 , 173-178, 180-181, 184, 188, 192; figs. 8, 10, 26, 47; tabs. 3-4; Armas, Alayón García, 1984: 9; Armas, 1989: 24-26, 29-30, 34, 36, 45; figs. 3, 5b, 14; Reddell, Cokendolpher, 1995: 1.
Rowlandius [in part: references to $R$. decui only]: Reddell, Cokendolpher, 1995: 6, 12, 19, 92, 159; Armas, 2001: 93, 95. Armas, 2002: 150, 164, 166; Harvey, 2003: 115-116, 367; Teruel, 2003: 59, 68; Armas, 2004: 18, 47; Armas, 2013: 93; Giupponi et al., 2016: 13, 25, 27-31; fig. 9; tabs. 1-2, 4.

TYPE SPECIES. Schizomus decui Dumitresco, 1977 [currently Dumitrescoella decui (Dumitresco, 1977), comb.n.], by both present designation and monotypy.

DIAGNOSIS. Size medium to moderately large for the family (3-4 mm). Coloration (Figs. 1-3): immaculate dark to blackish green, with chelicerae and pedipalps reddish. Body without clavate setae. Cheliceral movable finger (Fig. 4): ventrointernal margin with serrula and guard tooth, ventroexternal margin with a crenulate lamella progressively stronger distally. Pedipalps (Figs. 1-3, 5) sexually dimorphic and polymorphic: long and slender in heteromorphic males $v s$. short and robust in homomorphic males and females; trochanter with internal spur. Propeltidium without true ocelli, but with ordinary eyespots instead; anterior process with two apical setae $(1+1)$, dorsal setae sexually dimorphic: two pairs in males vs. five pairs (second submedian pair sometimes incomplete) in females. Metapeltidium entire. Tergites II-VII with setation unmodified but sexually dimorphic: standard formula $2 /$ $2 / 2 / 2 / 2 / 2$ in males $v s$. increased $2 / 4 / 6-8 / 8-10 /$ 10-12/14-16 (a few pairs sometimes incomplete) in females. Leg IV femur moderately robust, anterodorsal margin angled at $90^{\circ}$. Male: pedipalp patella and tibia in heteromorphics and homomorphics ventrodistally armed with large, dark, knife-like spiniform macrosetae (some of them arising from enlarged setiferous tubercles, denser and stronger in largest heteromorphics, see Fig. 5); heteromorphic with pedipalp trochanter elongate, with femoral articulation narrow and in anterodistal position, thus, with apex not produced. Abdomen (Figs. 6-7) not attenuate, abdominal segments XI-XII without modified setae; segment XII unmodified and with dorsoposterior process very weak, widely convex. Flagellum (Figs. 6-7) lanceolate, depressed and essentially flat, with pedicel/bulb angled roughly at $180^{\circ}$; pedicel medium-sized and compressed (remarkably deeper than wide); bulb dorsal surface with a conspicuous, round subdistal depression bordered anteriorly by a broadly Y-shaped dome; setation pattern: single $d m_{1}, d m_{4}, v m_{1}$ and $v m_{5}$, paired $d l_{1}, d l_{2}$, $d l_{3}, v m_{2}, v m_{3}, v l_{1}$ and $v l_{2}$, with $d m_{1}$ located at pedicelbulb junction, and $d m_{4}$ in subapical position inside the depression. Female: flagellum (Fig. 8) with four flagellomeres and three annuli; setation pattern per flagellomere: none / single $d m_{1}$ and $v m_{1}$, paired $d l_{1}$ and $v m_{2} /$ paired $d m_{3}, v m_{3}$ and $v m_{4} /$ single $d m_{4}$ and $v m_{5}$, paired $d l_{2}, d l_{3}, d l_{4}, v l_{1}$ and $v l_{2}$. Spermathecae (Fig. 9) with two pairs of very simple, match-shaped lobes: relatively short and slender, curved outwards (more strongly in the lateral pair, which is also somewhat longer), subcylindrical, with apical bulbs obsolete to vestigial. Chitinized arch well sclerotized, short and wide, cordiform. Gonopod large and widely oval.

COMPARISONS. The very strong sexual dimorphism in the dorsal setation of the propeltidium makes 


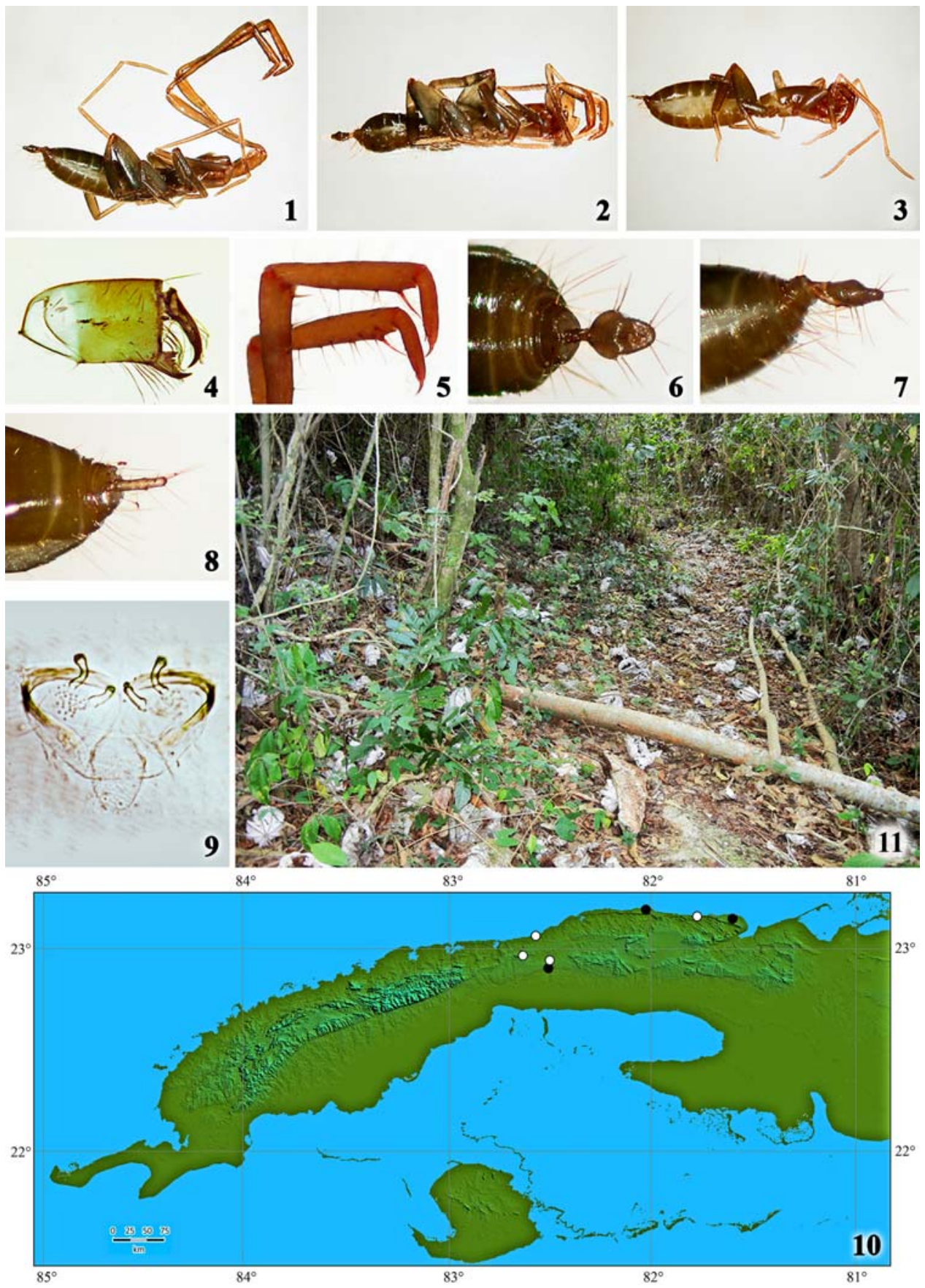

Figs. 1-11. 1-3 - freshly preserved adults of Dumitrescoella decui comb.n. from the source of the Ariguanabo River, lateral view: 1 - large heteromorphic male; 2 - homomorphic male; 3 - female. 4-7 - freshly preserved heteromorphic male of $D$. decui comb.n. from the source of the Ariguanabo River: 4 - right chelicera, external view; 5 - pedipalp patella (distal half only), tibia and tarsus, lateral view; 6-7 - abdominal segments VII-XII and flagellum, dorsal and lateral views. 8-9 - freshly preserved female of $D$. decui comb.n. from the source of the Ariguanabo River: 8 - abdominal segments VII-XII and flagellum, dorsolateral view; 9 - spermathecae. $10-$ map of western Cuba, showing the distribution of $D$. decui comb.n.: new records herein given (white dots), previous literature records (black dots). 11 - habitat of D. decui comb.n., at the exact collection site at the source of the Ariguanabo River.

Рис. 1-11. 1-3 - свежесобранные половозревые особи Dumitrescoella decui comb.n. из истоков реки Аригуанабо, латерально: 1 - большой гетероморфный самец; 2 - гомоморфный самец; 3 - самка. 4-7 - свежесобранный гетероморфный самец $D$. decui comb.n. из истоков реки Аригуанабо: 4 - правая хелицера, вид снаружи; 5 - колено педипальпы (только дистальная половина), голень и лапка, латерально; 6-7 - сегменты абдомена VII-XII и хвостовой отросток, дорсально и латерально. 8-9 - свежесобранная самка $D$. decui comb.n. из истоков реки Аригуанабо: 8 - сегметы абдомена VII-XII и хвостовой отросток, дорсолетарально; 9 - сперматеки. 10 - карта западной Кубы, показано распространение $D$. decui comb.n.: новые находки (белые точки), ранее известные литературные данные (черные точки). 11 - биотоп $D$. decui comb.n., в месте сбора материала в истоках реки Аригуанабо. 
Dumitrescoella gen.n. stand apart from almost all other Hubbardiinae (see further comments in Remarks section below). In particular, up to five pairs of dorsal setae in the female is a striking autapomorphy for the entire Hubbardiidae Cook, 1899; such numbers are so far restricted to members of Protoschizomidae Rowland, 1975.

Another character diagnostic for this genus amongst other hubbardiines is the increased setation pattern of female tergites which is shared only by four other genera: Antillostenochrus Armas et Teruel, 2002 (Greater Antilles), Clavizomus Reddell et Cokendolpher, 1995 (southeast Asia), Mayazomus Reddell et Cokendolpher, 1995 (western Central America) and Paradraculoides Harvey, Berry, Edward et Humphreys, 2008 (western Australia). All of them differ from Dumitrescoella gen.n. as follows:

Antillostenochrus. 1. Male pedipalp: patella greatly reduced, always the shortest segment in heteromorphics and shorter than at least both the femur and the tibia in homomorphics, trochanter in heteromorphics not elongated and conspicuously curved upwards, tibia in heteromorphics ventrally armed with two parallel rows of large, dark, knife-like spiniform macrosetae. 2. Spermathecae with all four lobes tubular and apically narrower. 3. Female flagellum with three flagellomeres and two annuli.

Clavizomus (data taken from original descriptions and figures of Reddell \& Cokendolpher [1995]). 1. Pedipalp trochanter lacking internal spur. 2. Entire body and legs covered with clavate setae. 3. Femur IV with anterodorsal margin angled at clearly less than $90^{\circ} .4$ Metapeltidium divided. 5. Male pedipalp: only slightly elongated and densely covered with thick spiniform setae. 6. Male flagellum: very long and slender, dorsal surface of bulb with two sharp submedian prominences followed by two deep submedian depressions. 7. Spermathecae lacking gonopod.

Mayazomus (data taken from descriptions and figures of the two most recent generic revisions of Monjaraz-Ruedas \& Francke [2015a-b]). 1. Heteromorphic male pedipalp: trochanter not elongate, with femoral articulation very wide and on mediodorsal position (i.e., approximately horizontal to the trochanter longitudinal axis) and with apex strongly produced into a triangular flat projection, femur and tibia each distally with a large ventrointernal spur, patella club shaped and strongly curved downwards. 2. Cheliceral movable finger with ventroexternal margin smooth, lacking any accessory teeth or lamella. 3. Spermathecae with median lobes usually longer than lateral lobes.

Paradraculoides (data taken from original description and figures of Harvey et al. [2008]). 1. General aspect completely different, troglomorphic: coloration pale yellowish, ocular eyespot absent. 2. Metapeltidium divided. 3. Homomorphic male with pedipalp trochanter lacking internal spur. 4. Male flagellum very different: short and stocky, with pedicel short, thick and deeper than bulb. 5. Female flagellum with three flagellomeres and two annuli. 6. Spermathecae with lateral and median lobes basally fused into a Y-shape. 7. Female gonopod bifurcate.

ETYMOLOGY. The selected generic epithet is feminine in gender and honors Margareta Dumitresco (formerly at Institut de Spéologie "Emile Racovitza", Bucharest, Romania) for her contributions to the knowledge of Cuban schizomids. More than 40 years later, the six species she described [Dumitresco, 1973, 1977] remain valid, and her descriptions still represent a hardto-match standard of detailed and exquisitely illustrated taxonomic work.

DISTRIBUTION (Fig. 10). Monotypic genus, endemic from western Cuba. Its single species $D$. decui comb.n. has been found in seven localities scattered across a roughly oval area of $110 \times 20 \mathrm{~km}$, in the northern watershed of the provinces of Artemisa, Mayabeque and Matanzas. It is also expected to occur in the few forest remnants of La Habana Province (= Havana City), such as those along the Quibú, Almendares and Bacuranao Rivers, which are in the center of the known distribution area and still have suitable habitats.

New records for Dumitrescoella decui comb.n. (Fig. 10). ARTEMISA Province: Caimito Municipality: Mesa de Anafe: Sierra del Esperón: La Inesita [= El Carburo]; $22^{\circ} 56^{\prime} 54^{\prime \prime} \mathrm{N}-82^{\circ} 37^{\prime} 46^{\prime \prime} \mathrm{W}, 140 \mathrm{~m}$ a.s.l.; 7.02.2015; T.M. Rodríguez; 1 (RTO). Bauta Municipality: Playa Baracoa; $23^{\circ} 01^{\prime} 41^{\prime \prime} \mathrm{N}-82^{\circ} 33^{\prime} 58^{\prime \prime} \mathrm{W}, 40$ $\mathrm{m}$ a.s.1.; 6.07.2015; T.M. Rodríguez; $1 \sigma^{7}$ heteromorphic (RTO). San Antonio de los Baños Municipality: source of Ariguanabo River, $4 \mathrm{~km}$ north of San Antonio de los Baños; 22 $55^{\prime} 27^{\prime \prime} \mathrm{N}-82^{\circ} 29^{\prime} 43^{\prime \prime} \mathrm{W}, 90 \mathrm{~m}$ a.s.1.; 31.12.2016; R. Teruel, S. Yong, R. Velázquez; 4 $\sigma^{7} \sigma^{7}$ heteromorphic, $1 \sigma^{7}$ homomorphic, 5 कO (RTO). MAYABEQUE Province: Santa Cruz del Norte Municipality: Boca de Canasí; $23^{\circ} 08^{\prime} 36^{\prime \prime} \mathrm{N}-81^{\circ} 46^{\prime} 22^{\prime \prime} \mathrm{W}$, 20 m a.s.1.; 13.09.2014; T.M. Rodríguez; 2 q (RTO).

Previous records for Dumitrescoella decui comb. n. (Fig. 10). MATANZAS Province: Matanzas Municipality: Bacunayagua: La Pluma Cave (type locality); 30.04.1973; V. Decu, Ş. Negrea; $2 \sigma^{7} \sigma^{7}$ heteromorphic, 3 + (ISER), see Dumitresco [1977]. ARTEMISA Province: San Antonio de los Baños Municipality: San Antonio de los Baños; 80 m a.s.l.; 4.06.1972; L.F. Armas; $1 \sigma^{7}$ heteromorphic (IES), see Rowland \& Reddell [1979]. Same locality, no further data specified; 1 $\sigma^{7}$ homomorphic (IES), see Armas [1989]. Same locality; 15.06.1987; L.F. Armas; $1 \sigma^{7}$ heteromorphic, 1 \% (IES), see Armas [2002]. MAYABEQUE Province: Santa Cruz del Norte Municipality: Boca de Jaruco: El Cable Cave; 18.10.1991; L.F. Armas, A. Pérez, A. Ávila; 1 (IES), see Armas [2002].

ECOLOGICAL NOTES. According to the published literature and personal data of the present author and his field collaborators, the single species of this genus is restricted to lowland (20-140 m above sea level) limestone areas of karstic relief covered by semicaducifolious forest (Figs. 10-11). It lives under rocks semi-buried in the leaf litter from the seashore to less than $20 \mathrm{~km}$ inland. 
This kind of landscape is abundant in cave formations and Dumitrescoella decui comb.n. has indeed been found in two caves, including the type locality [Dumitresco, 1977; Armas, 2002]; it is obviously a troglophile.

In all known localities, it lives syntopically with the hubbardiid Stenochrus portoricensis Chamberlin, 1922, which always outnumbers it markedly [Armas, 1989; R. Teruel, present data].

REMARKS. The four new localities recorded above for Dumitrescoella decui comb.n., include its first collections in Caimito and Bauta Municipalities (Artemisa Province), which extends its known geographical distribution $13 \mathrm{~km}$ westwards (Fig. 10).

It is intriguing that the two previous authorities that studied adults of both sexes of this schizomid (Margareta Dumitresco and Luis F. de Armas) did not notice the strong sexual dimorphism in setation of propeltidium and tergites, and gave only counts corresponding to male; even Armas [2001: 95] explicitly diagnosed the female (then placed in Rowlandius) as having only two pairs. It seems likely that these authors got the counts from the males and apparently assumed that the females did not differ, as no sexual dimorphism is typical in Hubbardiinae.

Specifically, regarding the setation of the propeltidium, only three cases of sexual dimorphism have been documented for Hubbardiidae: Rowlandius digitiger (Dumitresco, 1977) from eastern Cuba, Rowlandius dumitrescoae (Rowland et Reddell, 1979) from southern Costa Rica, and Rowlandius arenicola Teruel, Armas et Rodríguez, 2012 from central Cuba. All these records are included in the original descriptions; see Rowland \& Reddell [1979], Dumitresco [1977] and Teruel et al. [2012]. Of these, in the sister taxa $R$. digitiger and $R$. arenicola, the dimorphism is very slight and still included within the standard range for the family: only a one-seta modal difference, with both sexes having 2-3 pairs, the first count more common in males and the second in females [Teruel et al., 2012].

However, R. dumitrescoae deserves a separate discussion. The dimorphism is very similar to that of Dumitrescoella decui comb.n.: the male with two pairs $v s$. the female with four pairs, apparently without significant variation, i.e., Rowland \& Reddell [1979] studied three adults of each sex from two distinct populations and emphasized that they all have the same counts for each sex. Moreover, this species also resembles Dumitrescoella decui comb.n. in the shape of adult male pedipalps, abdominal sternite XII and flagellum, and segmentation of the female flagellum, which led Rowland \& Reddell [1979] to consider them both as close relatives. Nevertheless, $R$. dumitrescoae differs conspicuously in having a standard setation on tergites II-VII, female spermathecae with median lobes very long, strongly curved inwards and having large apical bulbs. These differences are genus-level diagnostic characters according to the current taxonomy of Schizomida, and the above-mentioned similarities are ran- domly found in other genera and species of hubbardiines. Thus, $R$. dumitrescoae is herein discarded as a potential member of Dumitrescoella gen.n.

Two other corrections are necessary. First, Rowland \& Reddell [1979: 192] stated that male Dumitrescoella decui comb.n. lacks the internal spur of the pedipalp trochanter and the greenish coloration found in other species of the "dumitrescoae" species-group. Nevertheless, the spur was described and depicted originally by Dumitresco [1977: 151-152; fig. 4c], and both characters are invariably present in the six adult males herein examined (Figs. 1-2 and 6-7, see also female in Figs. 3, 8).

Second, the drawing of the female spermathecae published by Armas [1989: fig. 5b] must be regarded as unreliable. It markedly deviates from both the original drawing of Dumitresco [1977: fig. 5b] and the photograph herein presented (Fig. 9), which otherwise match each other perfectly.

Last, Rowland \& Reddell [1979: 180] stated that the great resemblance of the adult males from the type locality and San Antonio de los Baños suggested that they all were conspecific. This conclusion is confirmed here and further supported by the perfect match of the spermathecae (another important diagnostic character), despite both populations being separated by almost $100 \mathrm{~km}$ (Fig. 10).

With the present addition, the schizomid fauna of Cuba is composed of 12 genera and 55 species, with 8 and 54 of them, respectively, endemic. The following key allows the reliable distinction of all genera:

1. Leg IV femur with anterodorsal margin angled at $65-83^{\circ}$ and sexually dimorphic: angle always much more acute in male.....

2

- Leg IV femur with anterodorsal margin angled at approximately $90^{\circ}$ and sexually non-dimorphic: angle identical to very similar in both sexes ...................................... 3

2. Leg IV femur with anterodorsal margin angled at $65-70^{\circ}$. Tergite I with posterior margin conspicuously notched medially. Male: flagellum with more than 40 setae, but lacking $d m_{4}$. Female: flagellum with $v m_{2}$ setae; spermathecae with median and lateral lobes long, slender and subcylindrical, the former clearly longer ................. Reddellzomus Armes, 2002

- Leg IV femur with anterodorsal margin angled at $70-83^{\circ}$. Tergite I with posterior margin not conspicuously notched. Male: flagellum with standard setation, $d m_{4}$ present. Female: flagellum lacking $\mathrm{v}_{2}$ setae; spermathecae with median and lateral lobes short, thick and pyriform, of similar length Heterocubazomus Teruel, 2007

3. Tergite I lacking anterior microsetae. Male: flagellum conspicuously trident-shaped in dorsal view: bulb with three very long, narrow and essentially parallel lobes; $d m_{4}$ seta located basally on bulb Cokendolpherius Armas, 2002

- Tergite I with 2-3 pairs of anterior microsetae. Male: flagellum variable in dorsal view, but never tridentshaped; $d m_{4}$ seta located subapically on bulb ............ 4

4. Habitus completely troglomorphic: coloration pale yellowish, with pedipalps light orange, eyespots absent, legs conspicuously attenuate. Male: abdominal segments XI-XII with highly modified macrosetae ................... 5 
- Habitus non-troglomorphic: coloration uniformly greenish or yellowish brown to blackish green, with pedipalps dark reddish, eyespots usually present, legs not especially attenuate. Male: abdominal segments XI-XII with standard setation

5. Pedipalp trochanter lacking internal spur. Male: abdominal segment XII with dorsoposterior process small and acute; flagellum lanceolate in dorsal view, with pedicel long and narrow, $d m_{1}$ seta located medially on pedicel. Female: spermathecae with median and lateral lobes cylindrical, basally fused into a V-shape .....

Cubacanthozomus Teruel, 2007

- Pedipalp trochanter with internal spur present. Male: abdominal segment XII lacking dorsoposterior process; flagellum round in dorsal view, with pedicel very short and wide, $d m$ seta located basally on bulb. Female: spermathecae with median and lateral lobes conical, not fused .......................... Troglocubazomus Teruel, 2003

6 . Tergite II with $4-8$ setae. Male: pedipalp patella conspicuously reduced, being always the shortest segment in heteromorphics and much shorter than at least both femur and tibia in homomorphics. Female: tergites IV-VII with 4-24 setae

Antillostenochrus Armas et Teruel, 2002

- Tergite II with only two setae. Male: pedipalp patella unmodified, always the longest segment or exceptionally just slightly shorter than femur only. Female: tergites IV-VII with only two setae.....

7. Male: flagellum bulb hexagonal in dorsal view, with a large, circular dorsomedial depression. Female: spermathecae with median and lateral lobes heavily sclerotized, club shaped and densely perforate by conspicuous glandular pores ............. Stenochrus Chamberlin, 1922

- Male: flagellum bulb variable in dorsal view, but never hexagonal nor with a large, circular dorsomedial depression. Female: spermathecae with median and lateral lobes variable, but never especially sclerotized and with surface entirely smooth or sparsely perforate by inconspicuous glandular pores ....

8. Metapeltidium clearly divided. Female: spermathecae with median and lateral lobes basally fused into a Y-shape and lacking apical bulbs; flagellum with three flagellomeres and two annuli

Cubazomus Reddell et Cokendolpher, 1995

- Metapeltidium entire (an incomplete pale median line may occur, but never a true division). Female: spermathecae with median and lateral lobes usually not fused, if so, then also at least one pair with well-defined apical bulbs and flagellum with four flagellomeres and three annuli ..... 9

9. Male: flagellum bulb globose in lateral view, with dorsal surface shallowly concave and lacking conspicuous sculpture or relief, ventral surface very strongly and abruptly convex. Female: flagellum with three flagellomeres and two annuli; spermathecae with 3-4 pairs of very short and thick lobes

Luisarmasius Reddell et Cokendolpher, 1995

- Male: flagellum depressed in lateral view, with dorsal surface flat to convex and with conspicuous sculpture or relief of protuberances, coarse carinae and/or small depressions and furrows, ventral surface shallowly to moderately convex. Female: flagellum with four flagellomeres and three annuli; spermathecae with only two pairs of lobes

10. Male: abdominal segment XII lacking dorsoposterior process; heteromorphic pedipalp tibia with a ventrodistal spur opposed to tarsus (replaced in homomorphic by a thick spiniform macroseta). Female: spermathecae with chitinized arch V-shaped, median and lateral lobes cylindrical and lacking apical bulbs .....

Guanazomus Teruel et Armas, 2002

- Male: abdominal segment XII with dorsoposterior process variable, but always present; heteromorphic pedipalp tibia variable, but always lacking a ventrodistal spur. Female: spermathecae with chitinized arch variable, but never V-shaped, median and lateral lobes variable, but either match-shaped or at least one pair with well-defined apical bulbs....

11. Cheliceral movable finger with a ventroexternal crenulate lamella. Male: abdominal segment XII with dorsoposterior process very weak. Female: tergites III-VII with 4-16 setae; spermathecae with median and lateral lobes match-shaped .................... Dumitrescoella gen.n.

- Cheliceral movable finger with several ventroexternal teeth. Male: abdominal segment XII with dorsoposterior process moderate to very strong. Female: tergites III-VII with only two setae; spermathecae with median and lateral lobes variable, but at least one pair with well-defined apical bulbs ....

Rowlandius Reddell et Cokendolpher, 1995

ACKNOWLEDGEMENTS. I am deeply indebted to my wife Sheyla Yong and her family for their support and hospitality at Havana, especially for helping with the collecting trip that yielded most of the specimens for this paper, and the assistance of her brother Raulito was critical. I also thank Tomás Michel Rodríguez Cabrera (Luyanó, Havana) for donating the rest of the schizomids herein studied and all the ecological information with them. Also, to Elier Fonseca Hernández (Universidad de La Habana), Axel Campos Castro and Margarita Sánchez Losada (both at Bioeco) for supplying the microscopy reagents and glassware. Last, but not least, to the anonymous referees for peer-review of the manuscript.

\section{References}

Armas L.F. 1989. Adiciones al orden Schizomida (Arachnida) en Cuba // Poeyana. Vol.387. P.1-45.

Armas L.F. 2001. A new Rowlandius Reddell \& Cokendolpher, 1995 (Schizomida: Hubbardiidae) from Navassa Island, Greater Antilles // Revista Ibérica de Aracnología. Vol.4. P.93-95.

Armas L.F. 2002. Nuevas especies de Rowlandius Reddell \& Cokendolpher, 1995 (Schizomida: Hubbardiidae) de Cuba // Revista Ibérica de Aracnología. Vol.6. P.149-167.

Armas L.F. 2004. Arácnidos de República Dominicana. Palpigradi, Schizomida, Solifugae y Thelyphonida // Revista Ibérica de Aracnología, Volumen Especial Monográfico. Vol.2. P.1-63.

Armas L.F. 2011. Género nuevo de Hubbardiidae (Arachnida: Schizomida) para Jamaica // Solenodon. Vol.6. P.12-19.

Armas L.F. 2013. Pedipalpi (Arachnida: Amblypygi, Schizomida, Thelyphonida) de Cuba occidental // Revista Ibérica de Aracnología. Vol.22. P.91-94.

Armas L.F., Alayón G. 1984. Sinopsis de los arácnidos cavernícolas de Cuba (excepto ácaros) // Poeyana. Vol.276. P.1-25.

Armas L.F., Teruel R. 1998. Taxonomía de Stenochrus brevipatellatus, comb. n. (Schizomida: Hubbardiidae) // Iheringia, Série Zoológica. Vol.85. P.47-49.

Dumitresco M. 1973. Deux espèces nouvelles du genre Schizomus (Schizomida), trouvées á Cuba // Résultats des expéditions biospéologiques cubano-roumaines à Cuba, Bucuresti: Editura Academiei. Vol.1. P. 279-292.

Dumitresco M. 1977. Autres nouvelles espèces du genre Schizomus des grottes de Cuba // Résultats des expéditions biospéologiques 
cubano-roumaines à Cuba. Bucuresti: Editura Academiei. Vol.2. P.147-158.

Giupponi A.P.L., Miranda G.S., Villarreal O.M. 2016. Rowlandius dumitrescoae species group: new diagnosis, key and description of new cave-dwelling species from Brazil (Schizomida, Hubbardiidae) // Zookeys. Vol.632. P.13-34.

Harvey M.S. 2003. Catalogue of the smaller arachnid orders: Amblypygi, Uropygi, Schizomida, Palpigradi, Ricinulei and Solifugae. Victoria: CSIRO Publ. 385 p.

Harvey M.S., Berry O., Edward K.L., Humphreys G. 2008. Molecular and morphological systematics of hypogean schizomids (Schizomida: Hubbardiidae) in semiarid Australia // Invertebrate Systematics. Vol.22. P.167-194.

Monjaraz-Ruedas R., Francke O.F. 2015a. Taxonomic revision of the genus Mayazomus Reddell \& Cokendolpher, 1995 (Schizomida: Hubbardiidae), with description of five new species from Chiapas, Mexico // Zootaxa. Vol.3915. No.4. P.451-490.

Monjaraz-Ruedas R., Francke O.F. 2015b. Systematics of the genus Mayazomus (Arachnida: Schizomida): the relevance of using continuous characters and pedipalp setae patterns to schizomid phylogenetics // Zoological Journal of the Linnean Society. Vol.2015. P.1-25.

Monjaraz-Ruedas R., Francke O.F. Cruz-López J.A., SantibáñezLópez C.E. 2016. Annuli and setal patterns in the ûagellum of female micro-whipscorpions (Arachnida: Schizomida): hypotheses of homology across an order // Zoologischer Anzeiger. Vol.263. P.118-134.
Reddell J.R., Cokendolpher J.C. 1995. Catalogue, bibliography and generic revision of the order Schizomida (Arachnida) // Speleological Monographs, Texas Memorial Museum. Vol.4. P.1-170.

Rowland J.M., Reddell J.R. 1979. The order Schizomida (Arachnida) in the New World. I. Protoschizomidae and dumitrescoae groups (Schizomidae: Schizomus) // Journal of Arachnology. Vol.6. P.161-196.

Rowland J.M., Reddell J.R. 1980. The order Schizomida (Arachnida) in the New World. III. mexicanus and pecki groups (Schizomidae: Schizomus) // Journal of Arachnology. Vol.8. P.1-34.

Teruel R. 2003. Adiciones a la fauna cubana de esquizómidos, con la descripción de un nuevo género y nueve especies nuevas de Hubbardiidae (Arachnida: Schizomida) // Revista Ibérica de Aracnología. Vol.7. P.39-69.

Teruel R. 2015. Nueva especie de Antillostenochrus Armas \& Teruel 2002 (Schizomida: Hubbardiidae), del extremo oriental de Cuba // Revista Ibérica de Aracnología. Vol.27. P.75-80.

Teruel R., Armas L.F., Rodríguez T.M. 2012. Adiciones a los esquizómidos de Cuba central, con las descripciones de cuatro nuevos Rowlandius Reddell \& Cokendolpher 1995 (Schizomida: Hubbardiidae) // Revista Ibérica de Aracnología. Vol.21. P.97-112.

Responsible editor K.G. Mikhailov 